\title{
Approach to Labial Fusion in Children: 16 Years of Experience
}

\author{
Çocuklarda Labial Füzyona Yaklaşım: 16 Yıllık Deneyim
}
Can İhsan Öztorun', ĐElif Emel Erten², Süleyman Arif Bostancı², Şükrüye Demirkaya², Ahmet Ertürk², SSabri Demir², DDoğuş Güney', CGülsen Keskin ${ }^{3}$, @Müjdem Nur Azılı', Emrah Şenel ${ }^{1}$

${ }^{1}$ Ankara Yıldırım Beyazıt University, Faculty of Medicine, Department of Pediatric Surgery, Ankara, Turkey

${ }^{2}$ Ankara City Hospital, Pediatric Surgery Clinic, Ankara, Turkey

${ }^{3}$ Health Sciences University, Dışkapı Yıldırım Beyazıt Training and Research Hospital, Department of Anesthesiology Ankara, Turkey

\section{ABSTRACT}

Aim: We aimed to retrospectively evaluate the patients with labial fusion who presented to or were referred to the pediatric surgery clinic in a tertiary pediatric hospital.

Material and Method: Between 01/01/2005 and 31/12/2020, 889 patients admitted or consulted to the pediatric surgery clinic due to labial fusion, age at the time of diagnosis, complaints on admission, which clinic referred the patient to the pediatric surgery clinic, treatments, recurrence, and complications were evaluated retrospectively.

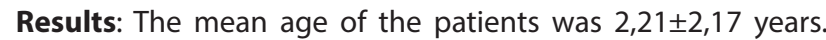
Most of the patients (82.5\%) were asymptomatic. Parents noticed the condition and brought their child directly to the pediatric surgery clinic in $72.3 \%$ of the cases. Otherwise, patients were consulted to the pediatric surgery clinic from pediatric clinics, the pediatric endocrinology clinic, the pediatric nephrology clinic, or the pediatric emergency department. During the initial examination, manual separation was performed in 885 patients, and surgery was required for four patients. After the procedures, hydrotherapy with warm water and topical estrogen therapy were applied to all patients for 15 days. Recurrence was detected in 80 (9.0\%) patients who were treated by manual separation. Manual separation was performed again in 78 of the patients, while surgical separation was performed in two $(2.5 \%)$ patients who had severe fibrotic fusions.

Conclusion: In the treatment of labial fusion, we recommend the combination of manual separation and topical estrogen cream treatment because it can be applied safely in the clinic, and the recurrence rate is low. Surgical separation is preferred in severe, thick, and fibrotic labial fusions.

Keywords: Girl, labial fusion, topical estrogen, manual separation, surgical separation

\section{ÖZ}

Amaç: 3. basamak bir çocuk hastanesinde çocuk cerrahisi polikliniğine başvuran veya konsülte edilen labial füzyonlu hastaları retrospektif olarak değerlendirmeyi amaçladık.

Gereç ve Yöntem: 01/01/2005-31/12/2020 tarihleri arasında çocuk cerrahisi kliniğine labial füzyon nedeni ile başvuran veya konsülte edilen 889 hasta tanı anındaki yaşları, başvuru şikâyetleri, hangi kliniklerden çocuk cerrahisine konsülte edildiği, tedavileri, nüks ve komplikasyonlar açısından retrospektif olarak değerlendirildi.

Bulgular: Hastaların yaşortalaması 2,21 22,17yıl idi. Hastaların çoğu asemptomatik idi $(\% 82,5)$. Hastaların \%72,3'ü ebeveynlerin fark etmesi ile doğrudan çocuk cerrahisi polikliniğine getirildi. Bunun dışında pediatri poliklinikleri, pediatrik endokrinoloji polikliniği, pediatrik nefroloji polikliniği ve çocuk acilden hastalar kliniğimize konsülte edildi. İlk muayenede, 885 hastaya manuel seperasyon ve 4 hastaya cerrahi uygulandı. Tüm hastalara işlemden sonra 15 gün boyunca ılık suya oturma banyosu ve topikal östrojen tedavisi uygulandı. Manuel seperasyon yapılan 80 (\%) hastada nüks tespit edildi. Nüks olan hastaların 78'ine yeniden manuel seperasyon yapılırken, sert fibrotik füzyonu olan iki hastaya $(\% 2,5)$ ise cerrahi seperasyon yapıldı.

Sonuç: Labial füzyon tedavisinde, manuel seperasyon ve topikal östrojenli krem tedavi kombinasyonunu, poliklinik ortamında güvenilir şekilde uygulanabilir olması ve nüks oranın düşük olmasından dolayı önermekteyiz. Sert, kalın ve fibrotik labial füzyonlarda ise cerrahi seperasyon tercih edilmelidir.

Anahtar Kelimeler: Kız çocuk, labial füzyon, topikal östrojen, manuel seperasyon, cerrahi seperasyon 


\section{INTRODUCTION}

Labial fusion is a benign gynecological pathology that occurs as a result of partial or complete adhesion of the labia minora to the midline in girls; it is mostly seen between 0-2 years of age. The prevalence of labial fusion is $1.8 \%$, with the highest incidence (3.3\%) at 13 to 23 months $(1,2)$. Although hypoestrogenism in the prepubertal periods considered to be the etiology, conditions such as urinary tract infections, diarrhea, diaper rash, fungal infections, allergic dermatitis, vaginal stream, poor hygiene, and low frequency of body washing and diaper changes can cause labial adhesions. Local trauma and irritation lead to fibrous exudate, causing tissue damage. Fibrous exudate is thought to cause midline adhesions (3). Although labial fusion is usually asymptomatic, it can cause problems such as bacteriuria, urinary tract infections, difficulty in urination, post-void dripping, and even hydronephrosis in total adhesions $(4,5)$. Urinary tract infection is both a risk factor and a clinical outcome for labial fusion. It can be identified by families during home care or physicians with a careful physical examination. On physical examination, it is observed that the labia minora is partially or totally adhered as a thin membrane (Figure 1). Physical examination is sufficient for diagnosis. It is necessary to be careful in terms of labial adhesions in girls who present to the clinic with the complaint of frequent urinary tract infections. In treatment, the labial fusion should be separated. In most polyclinic conditions, it is sufficient to open the adhesion with manual separation. The separation process is performed with a sterile blunttipped clamp. If manual separation is insufficient in recurrent or total adhesions, the adhesion is separated surgically under sedation $(3,6,7)$. After separation of adhesions, topical application with estrogencontaining cream two to three times a day for two weeks is recommended to reduce recurrence. In addition, the risk of recurrence is reduced by advising the family on warm baths, application of antibacterial cream, and ensuring good hygiene (8). In this study, we aimed to retrospectively evaluate the demographic data, complaints, consulting clinics, treatment, and results of patients with labial fusion who presented to or were consulted to the pediatric surgery clinic in a tertiary pediatric hospital.

\section{MATERIAL AND METHOD}

The study was carried out with the permission of Ankara City Hospital No. 2 Clinical Research Ethics Committee (Dated: 13/10/2021, decision no: E2-21-438). All procedures were carried out in accordance with the ethical rules and the principles of the Declaration of Helsinki.
Between 01/01/2005 and 31/12/2020, female patients who presented to the pediatric surgery clinic or were referred to the clinic due to labial fusion were included in the study. The patients' files were evaluated retrospectively using the hospital data processing system. The age of the patients at the time of diagnosis, complaints, which clinic they were referred from, treatments applied, frequency of recurrence of the fusion, and complications were examined.

After the family was informed about the treatment method and consent was obtained, the labial fusion was treated with manual separation with the help of a blunt-tipped sterile clamp. The parents were educated about the use of estrogen topical cream, warm baths, and care recommendations for 15 days. They were called for follow-up in 15 days. In the patients who had thick, hard, fibrous adhesions which were detected in the physical examination, that were not amenable to manual separation, the fusion was separated surgically with electrocautery under sedation after obtaining the consent of the family. The patients were discharged on the same day as outpatients. During the follow-up period, topical estrogen cream and warm baths were advised for 15 days postoperatively.

\section{Statistical Analysis}

Data analysis was performed with the Statistical Package for the Social Sciences (SPSS) version 15.0 (SPSS Inc., Chicago, IL). The numerical variables, age, and number of clinic admissions were expressed as mean \pm standard deviation and categorical variables were expressed as percentages (\%). The Kolmogorov-Smirnov or Shapiro-Wilk tests were used to determine whether the numerical variables were normally distributed. For the normally distributed variables, the mean values of the variables were analysed using the Student's t test and ANOVA testing. Cochrane $Q$ test was used to compare categorical variables. $\mathrm{P}<0.05$ was considered statistically significant for all variables.

\section{RESULTS}

This study included 889 girls who presented to or were referred to our clinic due to labial fusion. The mean age was $2.21 \pm 2.17$ years. There were 347 patients (39.0\%) under the age of one-year-old, 462 patients (52.0\%) aged $1-5$ years, and 80 patients (9.0\%) over the age of five. The complaints of the children were dermatitis in $72(8.1 \%)$ patients and urinary tract infection in 83 (9.3\%) patients. Among the patients, 734 (82.6\%) were asymptomatic. The parents noticed the problem and brought their child directly to the pediatric surgery clinic in 643 (72.3\%) of the cases. Labial fusion was detected during the routine physical examination of $112(12.6 \%)$ patients in pediatric clinics and 41 (4.6\%) patients in pediatric endocrinology clinics. It was identified in 83 (9.3\%) patients in pediatric 
nephrology polyclinics who were being investigated for the cause of urinary tract infections. These patients were referred to our clinic after the detection of labial fusion. Ten (1.1\%) patients were brought to the pediatric emergency department after their parents noticed the labial fusion and were referred to our clinic by pediatric emergency physicians. The number of clinic admissions is presented in Table 1. It was determined that direct presentation to the pediatric surgery clinic was the highest $(p=0.02)$. The mean age of the patients was evaluated according to the referring clinic and is shown in Table 2 . It was found that the mean age of the patients who were consulted to our pediatric surgery clinic from the pediatric emergency service was statistically lower $(p=0.016)$.

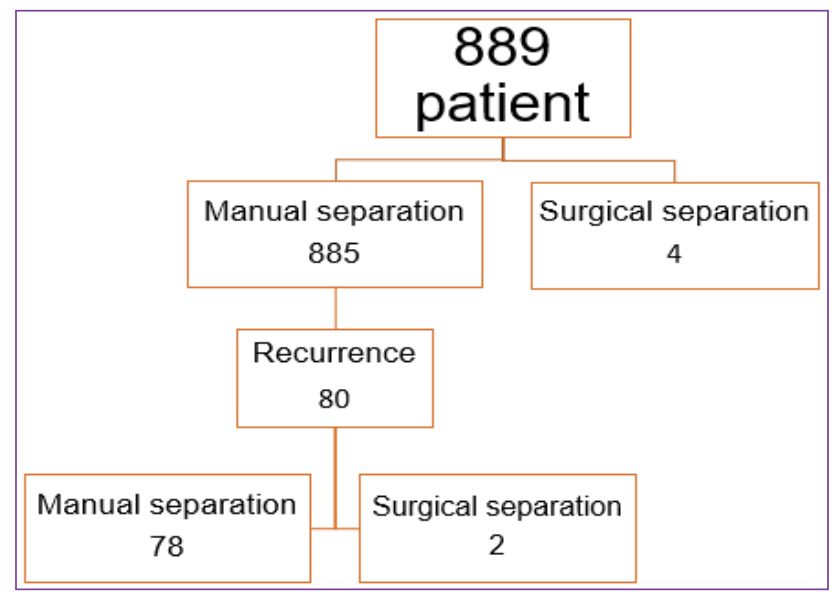

Figure 2. Treatment flow chart applied to the patients

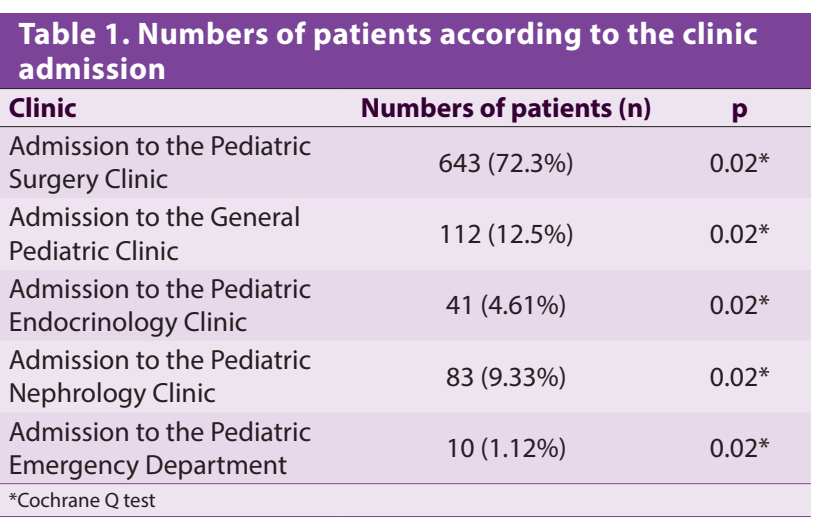

\begin{tabular}{|c|c|c|}
\hline Clinic & Mean age (year) & $\mathbf{p}$ \\
\hline $\begin{array}{l}\text { Admission to the Pediatric } \\
\text { Surgery Clinic }\end{array}$ & $2.26 \pm 3.42$ & $0.016^{*}$ \\
\hline $\begin{array}{l}\text { Admission to the General } \\
\text { Pediatric Clinic }\end{array}$ & $2.66 \pm 3.22$ & $0.016^{*}$ \\
\hline $\begin{array}{l}\text { Admission to the Pediatric } \\
\text { Endocrinology Clinic }\end{array}$ & $2.89 \pm 3.52$ & $0.016^{*}$ \\
\hline $\begin{array}{l}\text { Admission to the Pediatric } \\
\text { Nephrology Clinic }\end{array}$ & $2.45 \pm 2.87$ & $0.016^{*}$ \\
\hline $\begin{array}{l}\text { Admission to the Pediatric } \\
\text { Emergency Department }\end{array}$ & $0.6 \pm 0.5$ & $0.016^{*}$ \\
\hline${ }^{*}$ One -way ANOVA test & & \\
\hline
\end{tabular}

Escherichia coli $(\mathrm{n}=72,86.7 \%)$ was the most frequently seen microorganism in the urine culture of patients presenting with urinary tract infection, followed by Klebsiella pneumoniae $(n=7,8.4 \%)$ and Proteus species $(n=4,4.8 \%)$. The patients were given antibiotic treatment by the pediatric nephrologist in accordance with the urine culture.

A detailed genital examination was performed, and the labial fusion was opened in 885 patients by manual separation. After the initial examination, four patients who were not suitable for manual separation of their labial fusion were treated by surgical separation with electrocautery under sedation in the operating room. All patients received warm bath and topical estrogen therapy for 15 days after the procedure.

One hundred and fourteen (12.8\%) patients did not come to their follow-up examination. The patients were followed up for an average of $22 \pm 14$ months. The mean number of admissions to the clinic was $2.4 \pm 1,8$. During the follow-up, recurrence was detected in 80 (9.0\%) patients who were treated by manual separation. No recurrence was observed in the patients who were treated with surgical separation. Recurrence was detected at a mean of eight $8 \pm 7$ months. Manual separation was repeated in $78(97.5 \%)$ of the patients with recurrences, while surgical separation was performed in two (2.5\%) patients with severe fibrotic fusions (Figure 2).

The mean age of the patients was $2.6 \pm 2,4$ years in the relapsed group and 1.8 $\pm 1,6$ years in the non-relapsed group. The age of the patients was found to be higher in the group in which the fusion recurred $(p=0.03)$ (Student's t test). In 14 (17.5\%) of the relapsed patients, E. coli was detected in the urine culture. Manual separation and appropriate antibiotic therapy were applied.

\section{DISCUSSION}

Labial fusion is defined as partial or complete adhesion of the labia minora to the midline. There is a fusion starting from the posterior fourchette and progressing to the clitoris. Although hypoestrogenism is responsible for the etiology, diaper-related skin irritation, infections, and poor hygiene are considered the main factors $(9,10)$.

Labial fusion is common between three months and four years of age and peaks between 13 and 23 months (11). In this study, it was found that labial fusion was most common between the ages of one and five years, which is similar to the literature. It was seen in children younger than one year with the second highest frequency.

Most patients are asymptomatic and can be identified incidentally during care by parents or during a physical examination by a physician. They may present to 
pediatric surgery and pediatric clinics with symptoms such as dermatitis, dysuria, urinary tract infections, and obstruction $(10,11)$. Although $82.5 \%$ of the patients in this study were asymptomatic, there were patients who presented with dermatitis and urinary tract infections. In most of the patients $(72.3 \%)$ in this study, labial fusion was detected by the family who brought the patient directly to the pediatric surgery clinic. Some of the patients were referred to the pediatric surgery clinic by pediatricians after they detected labial fusion during the physical examination performed while investigating the etiology of urinary tract infection or incidentally during routine examinations in pediatric clinics. It was determined that the mean age of the patients who were referred to our clinic from the pediatric emergency service was statistically lower $(p=0.016)$. Although labial fusion is not a condition that requires emergency treatment, when families notice labial fusion during home care, they may want to have their baby treated immediately, thinking that the cause of the baby's trouble due to colic is labial fusion.

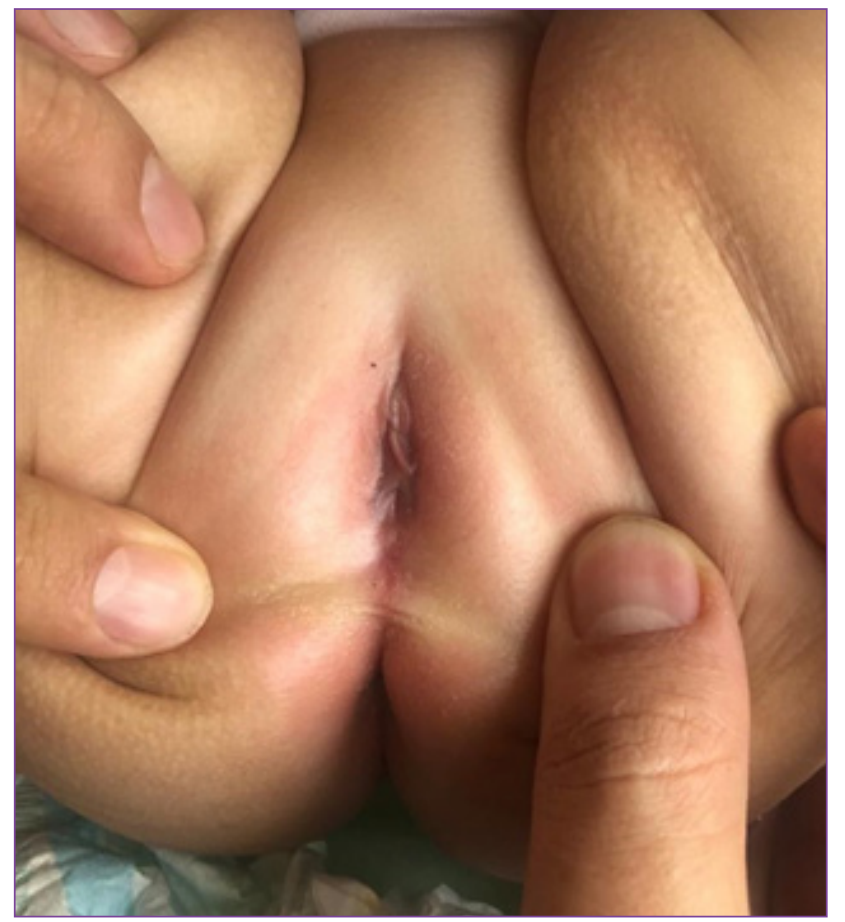

Figure 1. Total labial fusion in a girl infant.

There are different approaches in the literature regarding the treatment of labial fusion. It is thought that the increase in estrogen levels with puberty will cause spontaneous opening of the labial fusion. Some studies suggest waiting without intervention in asymptomatic cases (4). Other studies recommend treatment as labial fusion may cause asymptomatic bacteriuria and urinary tract infections (12). Our approach is to treat every labial fusion that comes to our clinic, even if it is asymptomatic, in order to prevent urinary system infections that may occur.
In addition to publications reporting failure of estrogen therapy in thick and nearly completely closed labial fusions, there are also reports of $50-88 \%$ success $(4,8,13)$. Manual separation is recommended in cases where topical estrogen therapy fails $(5,11,13)$. In the study by Soyer et al., manual separation and topical estrogen were applied together, and the success rate was reported as $100 \%$ (8). Saraç et al (12). compared estrogen therapy and manual separation therapy and found that manual separation was more successful.In some studies, surgery is recommended for patients with thick, hard, fibrous labial fusions $(1,5,13,14)$. In the present study, manual separation was performed in $99.5 \%$ of the patients,and topical estrogen therapy was applied initially. Surgical separation was performed under sedation in four patients with severe, thick labial fusions that were not suitable for manual separation.

Long-term use of topical estrogen is considered harmless, but there are publications reporting complaints, such as the onset of breast development, vulva discoloration, and vaginal bleeding $(1,4)$. Estrogen suppresses the local inflammatory response, accelerates epithelialization, and activates wound healing in the skin. Continuous application of cream to the fusion site creates a physical effect, causing the fusion to seperate.6 The application of topical estrogen cream is important to prevent recurrences, even if the fusion is separated manually (8). In this study, we prescribed estrogen-containing topical cream treatment for 15 days to patients who underwent both manual separation and surgery. We recommend using topical estrogen cream for 15 days after manual separation and surgical separation due to low recurrence rates.

In the literature, the recurrence rate was found to be $35-41 \%$ for topical estrogen treatment only, $14-25 \%$ for those who underwent manual separation only, and $11 \%$ for those who underwent surgical separation $(3,6,15)$. In the present study, the recurrence rate was $9.0 \%$ in the combination of manual separation and topical estrogen cream treatment, and there were no recurrences in those who underwent surgical separation. The recurrence rate in this study is lower than the rates reported in the literature. We think that the low recurrence rate is due to the success of the applied combined treatment and our detailed care recommendations for families.

In this study, recurrence was more common in older children. We think that this is due to frequent diaper changes and appropriate care during infancy, while reduced parental care after infancy, poor hygiene conditions and urinary tract infections

\section{CONCLUSION}

Labial fusion is seen frequently in prepubertal girls and is among the reasons for referral to both pediatric surgery clinics and pediatric and pediatric nephrology clinics due 
to urinary tract complaints in children. In the treatment of labial fusion, we recommend the combination of manual separation and topical estrogen cream treatment because it can be applied safely in the clinic, and the recurrence rate is low. Surgical separation should be preferred in severe, thick, fibrotic labial fusions.

\section{ETHICAL DECLARATIONS}

Ethics Committee Approval: The study was carried out with the permission of Ankara City Hospital No. 2 Clinical Research Ethics Committee (Dated: 13/10/2021, decision no: E2-21-438).

Informed Consent: Because the study was designed retrospectively, no written informed consent form was obtained from patients.

Referee Evaluation Process: Externally peer-reviewed.

Conflict of Interest Statement: The authors have no conflicts of interest to declare.

Financial Disclosure: The authors declared that this study has received no financial support.

Author Contributions: All of the authors declare that they have all participated in the design, execution, and analysis of the paper, and that they have approved the final version.

\section{REFERENCES}

1. Leung AKC, Robson WLM, Tay-Uyboco J. The incidence of labial fusion in children. J Paediatr Child Health 1993;29:235-6.

2. BalcıÖ, Karaman A, Ertürk A, et al. Puberte Öncesi Kız Çocuklarında Labial Füzyon. (Labial Fusion in Prepubertal Girls) Türkiye Çocuk Hastalıkları Derg 2015;9(3):195-7.

3. Mayoglou L, Dulabon L, Martin-Alguacil N, et al. Success of treatment modalities for labial fusion: a retrospective evaluation of topical and surgical treatments. J Pediatr Adolesc Gynecol 2009;22:247-50.

4. Tebruegge M, Misra I, Nerminathan V. Is the topical application of oestrogen cream an effective intervention in girls suffering from labial adhesions? Arch Dis Child 2007;92:268-71.

5. Velander $\mathrm{MH}$, Mikkelsen DB, Bygum A. Labial agglutination in a prepubertal girl:effect of topical oestrogen. Acta Derm Venereol 2009;89:198-9.

6. Schober J, Dulabon L, Martin-Alguacil N, et al. Significance of topical estrogens to labial fusion and vaginal introital integrity. J Pediatr Adolesc Gynecol 2006;19(5):337-9

7. Soylu A, Sarıer M, Davarcı M, et al. Labial füzyonun olduğu işeme zorluğu. (Labial fusion causing micturitional disturbance). Turk Urol J 2004;30(1):117-9.

8. Soyer T. Topical estrogen therapy in labial adhesions in children:therapeutic or prophylactic? J Pediatr Adolesc Gynecol 2007;20:241-4

9. Acer T, Ötgün İ, Öztürk Ö, et al. Do hygienic factors affect labial fusion recurrence? A search for possible related etiologic factors. J Pediatr Surg 2012 Oct 1;47(10):1913-8.

10. Türk E, Karaca İ. Prepubertallabial füzyonda tedavi yöntemleri. (Treatmentmethods in prepubertallabialfusion) Izm Univ Med 2014;3:33-6

11. Goldman RD. Child health update: estrogen cream for labial adhesion in girls. Can Fam Physician 2013;59:37-8.

12. Saraç F, Büyükbeşe $S S$, Toptaş $M$, Saygılı A, Şahin K. Labial Füzyonda Tedavi Yaklaşımlarımız. (Approaches to the Treatment of Labial Fusion) Medical Bulletin of Haseki/Haseki Tip Bulteni. 2016;54(2)
13. Eroğlu E, Yip M, Oktar T, Kayıran SM, Mocan H. How should be treat prepubertal labial adhesions? Retrospective comparison of topical treatments: Estrogen only, betamethasone only, and combination estrogen and betamethasone. J Pediatr Adolesc Gynecol 2011;24:389-91.

14. Silva D, Jayalath GK, Ranaweera AK, Jayawardane M, Sudeshika MD. A new method of surgical treatment for recurrent labial adhesions in a pre-pubertal girl. Ceylon Med J 2012;57:168-9.

15. Soyer T. Labialsynechia, imperforatedhymen, vaginalagenesis, atresia and stenosis. Turkiye Klinikleri J Pediatr Surg-Special Topics 2009;2(1):57-64. 